\title{
Correction to: Tetra chlorobenzoxazolamine nickel (II) phthalocyanine supercapacitor with aqueous electrolyte and MWCNTs
}

\author{
N. Y. Praveen Kumar ${ }^{1} \cdot$ Mounesh Mounesh $^{1} \cdot$ T. M. Sharanakumar ${ }^{2} \cdot$ K. R. Venugopala Reddy ${ }^{1}$
}

Published online: 17 April 2021

C Institute of Chemistry, Slovak Academy of Sciences 2021

\section{Correction to: Chemical Papers}

https://doi.org/10.1007/s11696-021-01523-z

In the original version of this article, unfortunately the coauthor name is incorrectly published.

Previously read as: Mounesh Mounesh.

It should read as: Mounesh.

The original article has been corrected.

Publisher's Note Springer Nature remains neutral with regard to jurisdictional claims in published maps and institutional affiliations.

The original article can be found online at https://doi.org/10.1007/ s11696-021-01523-z.

K. R. Venugopala Reddy

venurashmi30@gmail.com

1 Department of Studies and Research in Chemistry,

Vijayanagara Sri Krishnadevaraya University,

Ballari 583105, Karnataka, India

2 Ballari Institute of Technology and Management,

Ballari 583104, Karnataka, India 